\title{
EFFECT OF FEEDING AT DIFFERENT LEVELS OF WHEAT BRAN AND DATE SEEDS POWDER ON DIABETIC RATS
}

Mona M. Khalil; M. A. Abou-Raya; Gehan. A. Ghoniem and T. S. Hussain Food Industries Dept; Fac. of Agric., Mansoura Univ.; Egypt

\begin{abstract}
There is a global rise in the incidence of diseases like diabetes mellitus, atherosclerosis and cardiovascular diseases. Therefore, this study was designed to examine the effect of adding fine bran and date seeds powder as a sources of dietary fibers and active healthy components to prepare functional bread for lowering blood glucose and cholesterol levels. Sensory evaluation revealed that successful replacement of bread samples with 5,10 and $15 \%$ fine bran (Fb), 5 and $10 \%$ date seeds powder (Dsp) and the mixture of $5 \%$ fine bran $+5 \%$ date seeds powder. Bread supplemented with 10 and $15 \%$ fine bran contained $13.478 \%$ and $13.777 \%(\mathrm{~g} / 100 \mathrm{~g})$ protein content respectively, while bread supplemented with mixture of $5 \%$ fine bran $+5 \%$ date seeds powder, and $10 \%$ date seeds powder contained 5.51 and $4.95 \mathrm{~g} /$ $100 \mathrm{~g}$ ) of total dietary fibers respectively. The biological evaluation showed that rats fed on bread sample and its mixtures containing $15 \%$ fine bran, $5 \%$ date seeds powder, $10 \%$ date seeds powder and the mixture of $5 \%$ fine bran $+5 \%$ date seeds powder for 30 days significantly $(p<0.05)$ reduced serum total cholesterol (TC), triglycerides (TG), low density lipoproteins (LDL), very low density lipoproteins (vLDL), while high density lipoproteins (HDL) increased. Also, data showed that rats fed on pan bread made from wheat flour substituted with different levels of fine bran and/or date seeds powder significantly lowered their blood glucose level.

Keywords: fine bran, date seeds powder, pan bread, chemical composition, blood glucose.
\end{abstract}

\section{INTRODUCTION}

Mixtures with higher fibers content are good sources to produce low caloric food suitable to diabetic person. Additionally such diets are very effective to decrease the serum cholesterol ratio. So it is the reason for incurring some other disease such hypertension, heart disease, cancers...etc. (FDA, 2001).

High-fibers diet should contain between 20 and 35 grams of fibers a day. This is actually the quantity recommended for the general adult population, however most Americans eat only 15 grams of fibers per day. (ADA, 2001). Also, studies have showed that more people consuming less fibers in food, the incidence of non-infectious diseases is more repeated than in those taking larger quantities of fibers.

Diabetes is a growing problem in the current modern society. It is difficult to estimate the total number of population suffering from this problem. In year of 2004,according to the world health organization, more than 150 million people worldwide suffered from diabetes. Its incidence is increasing rapidly, and it is estimated that by the year of 2025, this number will be double. Diabetes mellitus happens throughout 
the world, but is more common in the more developed countries. The increase in incidence of diabetes in the developing nations follows the trend of development and life style changes. (Mohamed, 2006).

Wheat bread is an Egyptian product that represents the main diet component for rich and poor Egyptian consumers. In Egypt, there is a big gap between wheat production and its consumption, where the total production of wheat grains covers only about $55 \%$ of the total needs, one of the ways to overcome this problem is to search for other native cereal sources or else which could be used with wheat flour bread making, (Litwinek et al., (2013).

Wheat bran is used as a supplemental source of dietary fiber for preventing colon diseases (including cancer), preventing gastric cancer, treating Irritable bowel Syndrome (IBS), reducing the risk of hemorrhoids and hiatal hernia, hypercholesterolemia, hypertension, reducing the risk of breast cancer and gall bladder disease and type 2 diabetes. Wheat is an excellent source of iron and phosphorous. The outer layer of the barn provides fibers that gives bulk and regulates the absorption and excretion of nutrients from the body as mentioned by (Kumar et al., 2011).

Few researches have been published regarding incorporation of date seeds powder with wheat flour to prepare bread with higher degree of acceptability. Date seeds, which constitute $6-15 \%$ of the total weight of the ripe date, are largely produced in the Middle East and especially in the United Arab Emirates (UAE). In year of 2004, the world production of date seeds reached approximately 863 thousand tons. Although, a high nutritional value is well-recognized for date seeds, they are being wasted in large quantities or used for animal feed of such as camels, cattle, sheep, and poultry. The nutritional value of date seeds is mainly related to a significant amount of dietary fibers and a high content of polyphenols. Dietary fibers are particularly well-known for their potential benefits on cancer and type 2 diabetes prevention. Polyphenols, including chemical compounds like phenolic and flavonoids, are common constituents of the human diets, with fruits and vegetables being the major dietary sources of these bioactive compounds. Their possible health benefits have been suggested to derive from their antioxidant properties by chelating redoxactive metal ions, inactivating lipids free radical chain reactions, preventing hydroperoxide conversion into reactive oxradicals, and from their antiinflammatory properties as described by Hosam et al., 2004).

So, this study was designed to evaluate fine bran and date seeds powder as a source of dietary fibers and active healthy nutrients which has beneficial affect for lowering blood glucose and plasma cholesterol levels. 


\section{MATERIALS AND METHODS}

\section{Materials :}

Wheat flour (82\% extraction), and wheat fine bran, were obtained from the "Eastern Delta Flour Mills Company, Mansoura City, Egypt.

Date seeds (Zahdi variety) was obtained from dates molasses factory at Al-anbar governorate, Iraq.

Other ingredients such as sugar, fat, salt, dry yeast, milk powder and improvers were collected from the local market, Mansoura City, Egypt.

All Chemicals (analytical grade) were purchased from Company for Chemical and Medical Preparations, Dokki, Cairo, Egypt.

Male albino rats were obtained from the Medical Experimental Research Center, Faculty of Medicine, Mansoura University.

\section{Methods :}

\section{Date seeds preparation:}

Date seeds were washed well with tap water and finally with distilled water, then dried in an electric oven (GARBUIO, made in Italy) at $60{ }^{\circ} \mathrm{C}$ for 5 hours. Dried seeds were crushed and milled by milling machine TAMMEPOO (Denmark) for $10 \mathrm{~min}$ to pass through 60 mesh sieve.The powder was kept in polyethylene bags and stored at $-18^{\circ} \mathrm{C}$ for further analysis.

\section{Pan bread preparation:}

The conventional dough method for bread was performed according to the routine method according to A.A.C.C, (2000). The ingredients were mechanically mixed for $12 \mathrm{~min}$ in kneading machine by IMPASTATRICE (Italy) and then dough was divided into equal parts and rested for $2 \mathrm{hr}$, then molded to loaves. Wheat flour were substituted with fine bran and or date seeds powder for the two types for making pan bread at different levels at the levels of $5,10,15$ and $20 \%$ for each of them, wheat bread and their blends are shown in Table (1). Sensory evaluation of pan bread :-

Pan bread samples were evaluated organoleptically by a panel of 10 arbitrators for: appearance (20), crust color (10), crumb color (10), distribution of crumb (20), homogenous (10), taste (20), odor (10), and total acceptability, as the method described by. A.A.C.C, (2000). 
Table (1): Formula used in supplementing pan bread with fine bran and date seeds powder.

\begin{tabular}{|c|c|c|c|c|c|c|c|c|c|c|c|}
\hline \multirow[b]{2}{*}{ Ingredients } & \multicolumn{11}{|c|}{ Formulation of pan bread } \\
\hline & $\mathbf{A}$ & B1 & B2 & B3 & B4 & C1 & \begin{tabular}{|l|} 
C2 \\
\end{tabular} & \begin{tabular}{|l|} 
C3 \\
\end{tabular} & C4 & D1 & D2 \\
\hline $\begin{array}{ll}\text { Wheat } & \text { flour(82\%) } \\
(\mathrm{g}) & \\
\end{array}$ & 100 & 95 & 90 & 85 & 80 & 95 & 90 & 85 & 80 & 90 & 80 \\
\hline Fine bran $(\mathrm{g})$ & 0 & 5 & 10 & 15 & 20 & 0 & 0 & 0 & 0 & 5 & 10 \\
\hline Date seeds $(\mathrm{g})$ & 0 & 0 & 0 & 0 & 0 & 5 & 10 & 15 & 20 & 5 & 10 \\
\hline Sugar $(\mathrm{g})$ & 5 & 5 & 5 & 5 & 5 & 5 & 5 & 5 & 5 & 5 & 5 \\
\hline Fat $(\mathrm{g})$ & 5 & 5 & 5 & 5 & 5 & 5 & 5 & 5 & 5 & 5 & 5 \\
\hline Salt $(\mathrm{g})$ & 1 & 1 & 1 & 1 & 1 & 1 & 1 & 1 & 1 & 1 & 1 \\
\hline Milk powder $(\mathrm{g})$ & 2 & 2 & 2 & 2 & 2 & 2 & 2 & 2 & 2 & 2 & 2 \\
\hline Active dry yeast $(\mathrm{g})$ & 1.5 & 1.5 & 1.5 & 1.5 & 1.5 & 1.5 & 1.5 & 1.5 & 1.5 & 1.5 & 1.5 \\
\hline Improver (g) & 1 & 1 & 1 & 1 & 1 & 1 & 1 & 1 & 1 & 1 & 1 \\
\hline
\end{tabular}

A: $\mathbf{1 0 0 \%}$ wheat flour (control)

B3: $15 \%$ fine bran

B1: $5 \%$ fine bran

B2: $10 \%$ fine bran

C2: $10 \%$ date seeds powder

B4: $20 \%$ fine bran

C1: $5 \%$ date seeds powder

D1:A mixture of $5 \%$ fine bran $+5 \%$ date seeds powder

D2: A mixture of $10 \%$ fine bran $+10 \%$ date seeds powder.

\section{Analytical methods}

\section{Gross chemical analysis :}

Moisture, crude protein, fat, crude fibers and ash were determined according to the method of the A.O.A.C (2007).

The percentage of carbohydrate were calculated by difference as the following equation :- Carbohydrates $\%=100-(\%$ fibers $+\%$ protein $+\%$ fat $+\%$ ash ).

\section{Biological evaluation:.}

Experimental animals and diets:

Fifty four wister strain male albino rats weighting between 150-180 gm were used in this experiment. Animals were housed in cages under normal healthy laboratory conditions at $25{ }^{\circ} \mathrm{C} \quad 12 \mathrm{hr}$ light and $12 \mathrm{hr}$ dark). The animals were fed on basal diet for 7 days as adaptation period prior to start of the experiments. Basal diet are presented in Table (2) salt and vitamin mixtures as described by A.O.A.C (2005). 
Table (2): Composition of the basal diet:

\begin{tabular}{|l|c|}
\hline Ingredient & Basal diet(g/100g) \\
\hline Corn Starch & 70 \\
\hline Casein & 10 \\
\hline Fat (Corn oil) & 10 \\
\hline Salt mixture & 4 \\
\hline Vitamins mixture & 1 \\
\hline Cellulose & 5 \\
\hline
\end{tabular}

A.O.A.C (2005).

Preparation of diabetes rats:

Pure fine chemical was used for induction diabetes in normal healthy male albino rats by intraperiponeal injection of streptozetocin, $40 \mathrm{mg} / \mathrm{kg}$ body weight, softened in citric acid $(0.95 \mathrm{gm})$, Na citrate $(1.47 \mathrm{gm})$ and are dissolved in $100 \mathrm{ml} \mathrm{NaCl}$ "Salin" (0.9\%) according to the method described by Desai and Bhide, (1985).

Experimental design:.

After feeding on basal diet for 7 days (adaptation period). After acclimation, rats were randomly divided into (9) groups (each of 6 rats) six rats were kept as a control which fed on basal diet during the experimental period G1 (negative control). The other groups (diabetic rats) from G2 to G9 were fed with high-fibers diet. All groups of rats were fed the experimental diets for 30 days according to the following groups:

Group(1):Rats fed on basal diet (Negative control).(- ev control).

Group(2):Diabetic rats fed on basal diet (positive control).(+ev control).

Group(3):Diabetic rats fed on basal diet with $100 \%$ wheat flour $(82 \%)$ control sample).

Group (4):Diabetic rats fed on basal diet with pan bread (95\% wheat flour $+5 \%$ fine bran).

Group (5): Diabetic rats fed on basal diet with pan bread $(90 \%$ wheat flour $+10 \%$ fine bran).

Group (6): Diabetic rats fed on basal diet with pan bread (85\% wheat flour $+15 \%$ fine bran).

Group (7): Diabetic rats fed on basal diet with pan bread (95\% wheat flour $+5 \%$ date seeds powder ).

Group (8): Diabetic rats fed on basal diet with pan bread $(90 \%$ wheat flour $+10 \%$ date seeds powder ).

Group (9): Diabetic rats fed on basal diet with pan bread $(90 \%$ wheat flour $+5 \%$ fine bran $+5 \%$ date seeds powder ).

Through 30 days of the biological experimental, gain in body weight and food intake were recorded weekly.

\section{Blood Collection:.}

Rats were anesthetized, using diethyl ether. Blood samples of all the previously mentioned groups were taken at zero time, after 2 and 4 weeks from feeding with diet, then at the end of the experiment. The blood were collected after 12 hours fasting 
from vein plexus eye and left to clot in water bath $\left(37^{\circ} \mathrm{C}\right)$ at room temperature for half hour. The blood was centrifuged for 10 minutes at $3000 \mathrm{rpm}$ to separate the serum, which was kept frozen at $-18{ }^{\circ} \mathrm{C}$ in clean dry plastic tubes until analysis EL- Hadidy, (2009). Glucose was determined directly according the method recommended by Trinder., (1969).

Biochemical analysis:

Serum total cholesterol was determined according to the method described by Allain, et al. (1974). Triglycerides were determined according to the method described by Fossati and Principe (1982). Serum HDL-cholesterol was determined by the method of LopezVirell et al., (1977). Serum Low Density Lipoprotein (LDL-cholesterol) and very low density Lipoprotein (vLDL-cholesterol) were determined by the method of Fried Wald et al., (1972). Serum glucose level was analyzed through enzymatic calorimetrically procedures sets developed by Diamond Diagnostics,Cairo- Egypt according to Trinder, (1969).

\section{Statistical analysis:}

Data was analyzed using analysis of variance. Significance was used at $P .<0.05$. (ANOVA) to determine significant difference among the various samples. Data were analyzed by using means of Statistical Analysis System of Steel and Torie (1980).

\section{RESULTS AND DISCUSSION}

\section{Gross chemical composition of wheat flour( $82 \%$ ext.), fine bran} and date seeds powder (on dry weight basis):.

Wheat flour(82\% ext.), fine bran and date seeds powder (Zahdi variety.) were analyzed for moisture, protein, ash, crude fibers and carbohydrates, and the results are presented in Table (3). Data in this Table indicated that the date seeds powder were the highest in moisture content (13.32\%) followed by wheat flour $82 \%$ ext. $(12.74 \%)$ and fine bran $(11.20 \%)$. The obtained results are in agreement with data reparted by Abd El-Monem, (1994), who found that the moisture content of fine bran was $10.87 \%$.

Crude protein was the highest in wheat flour (82\% ext.) $11.38 \%$ while the lowest value of protein content was found in fine bran and date seeds powder $(8.97 \%$ and $6.29 \%$, respectively). These findings are in agreement with those reported by Soliman et al., (1993). They found that moisture content, fat, crude protein, ash, crude fibers and total carbohydrates of wheat flour (82\% ext.) were $11.06 \%$, $0.79 \%, 12.35 \%, 1.12 \%, 0.89 \%$, and $84.85 \%$ of wheat flour ( $82 \%$ ext.). The studied samples showed that fat content was the highest in date seeds powder $(8.74 \%)$, followed by fine bran $(1.73 \%)$, while the lowest value for wheat flour $(0.98 \%)$. These results agree with those recorded by Al-Farsi et al, (2007). From the same Table, fat 
content of date seeds powder was $8.74 \%$, crude protein $(6.29 \%)$, ash $(1.15 \%)$, and fibers $(28.5) \%$, these finding is in agreement with results obtained by Ammar et al., (2010) and Rahman et al., (2007) that the date seeds powder contained fiber of $(28.5 \%)$, fibers while fine bran followed by wheat flour recorded $(7.02 \%),(0.82 \%)$ respectively. Ash content of the ingredients used in this study showed the highest value in dried fine bran $(3.9 \%)$, followed by date seeds powder $(1.15 \%)$, and wheat flour $(0.92 \%)$. These results are in agreement with those reported by Hassan, (2003), that fine bran contained $4.46 \%$. The highest values of carbohydrates are recorded for wheat flour (82\% ext.) $(85.9 \%)$ followed by fine bran $(78.38 \%)$ and date seeds powder $(55.32 \%)$. These results are in agreement with those reported by Hassan, (2003) that total carbohydrates was $81.94 \%$.

Table (3): Gross chemical composition of wheat flour(82\% ext.), fine bran and date seeds powder $(\mathrm{g} / \mathrm{100g}$ ) (on dry weight basis).

\begin{tabular}{|l|c|c|c|c|c|c|}
\hline Sample & $\begin{array}{c}\text { Moisture } \\
\%\end{array}$ & $\begin{array}{c}\text { Protein } \\
\%\end{array}$ & $\begin{array}{c}\text { Fat } \\
\%\end{array}$ & $\begin{array}{c}\text { Crude } \\
\text { Fibers \% }\end{array}$ & $\begin{array}{c}\text { Ash } \\
\%\end{array}$ & $\begin{array}{c}\text { Total } \\
\text { Carbohydrates } \\
\%\end{array}$ \\
\hline Wheat flour ^2\% ext.(WF) & 12.74 & 11.38 & 0.98 & 0.82 & 0.92 & 85.9 \\
\hline Fine bran (FB) & 11.20 & 8.97 & 1.73 & 7.02 & 3.9 & 78.38 \\
\hline Date seeds powder(DSP) & 13.32 & 6.29 & 8.74 & 28.5 & 1.15 & 55.32 \\
\hline
\end{tabular}

\section{Sensory evaluation of pan bread samples produced from} wheat flour

(82\% ext.) containing different levels of fine bran and date seeds powder:.

Data illustrated in Table (4) showed that the average of sensory panel scores of appearance, crust color , crumb color, distribution of crumb, homogenous, taste, and odor. The data indicated that control sample No. (1) which contained $100 \%$ wheat flour $(82 \%$ ext.) recorded the highest total acceptability value 89.00 $\%$, followed by samples No. (2), (3), (4), (6), (10) and (7), they recorded $80.40 \%, 75.40 \%, 71.60 \%, 71.10 \%, 70.40 \%$, and $67.40 \%$, respectively. It could be noticed that there were non-significant difference between samples No. (3), (4), (6) and (10). While the lowest total acceptability scores was recorded for samples No. (5), (11), (8) and (9). They recorded $64.10 \%, 59.40 \%, 58.40 \%$ and $46.50 \%$, respectively. And these samples were refused. These variation related to the component of raw materials. On the other side these results agree with those obtained by Park et al., (1997) and Hassan, (2003) they found that adding different sources of fiber in pan bread making decreased organoleptic properties.

It can be concluded that the most acceptable pan bread samples were (1), (2), (3), (4), (6), (7), and (10).

So, these samples were chosen for chemical analysis and biological evaluation. 
Table (4): Sensory evaluation of pan bread samples produced from wheat flour (82\%ext.) containing different levels of fine bran and date seedspowder:.

\begin{tabular}{|c|c|c|c|c|c|c|c|c|c|}
\hline \multicolumn{2}{|c|}{ Samples } & \multirow{2}{*}{ 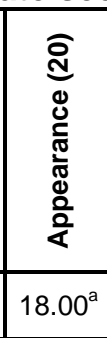 } & \multirow{2}{*}{ 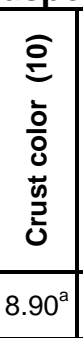 } & \multirow{2}{*}{ 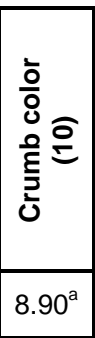 } & \multirow{2}{*}{ 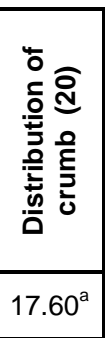 } & \multirow[t]{2}{*}{ 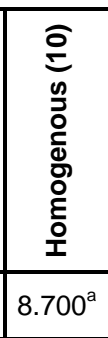 } & \multirow{2}{*}{ 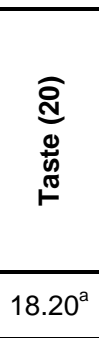 } & \multirow{2}{*}{ 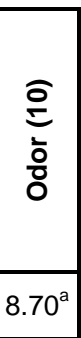 } & \multirow[t]{2}{*}{ 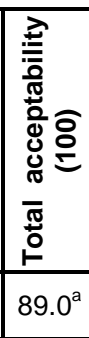 } \\
\hline No.(1) & $\begin{array}{l}100 \% \text { Wheat flour(82\% } \\
\text { ext.) }\end{array}$ & & & & & & & & \\
\hline o.(2) & $\begin{array}{l}95 \% \text { WF }(82 \% \text { ext. })+ \\
5 \% \text { FB }\end{array}$ & $16.50^{\mathrm{ab}}$ & $7.70^{\mathrm{ab}}$ & $8.20^{\mathrm{ab}}$ & $15.90^{\mathrm{ab}}$ & $7.800^{\mathrm{ab}}$ & $16.70^{a b}$ & $7.60^{\mathrm{ab}}$ & $80.4^{\mathrm{ab}}$ \\
\hline No.(3) & $\begin{array}{l}90 \% \text { WF( }(82 \% \text { ext. })+ \\
10 \% F B\end{array}$ & $15.70^{\mathrm{abc}}$ & $7.30^{\mathrm{ab}}$ & $7.50^{\mathrm{abc}}$ & $15.20^{a b c}$ & $7.400^{\mathrm{ab}}$ & $15.40^{\mathrm{bc}}$ & $6.90^{\mathrm{ab}}$ & 75.4 \\
\hline o.(4) & $\begin{array}{l}85 \% \quad W F(82 \% \\
15 \% \text { FB }\end{array}$ & sed & $6.90^{\mathrm{ab}}$ & 7 & & $6.900^{\mathrm{ab}}$ & cde & $6.80^{\mathrm{ab}}$ & $71.6^{\mathrm{bc}}$ \\
\hline No.(5 & $\begin{array}{l}80 \% \\
20 \%\end{array}$ & $13.70^{\mathrm{bcd}}$ & $6.30^{\mathrm{bc}}$ & $6.70^{\mathrm{abc}}$ & $12.90^{\mathrm{bcd}}$ & $5.700^{b c}$ & $13.00^{\mathrm{de}}$ & $5.80^{\mathrm{bc}}$ & 64.1 \\
\hline . 6 & $\begin{array}{l}95 \% \text { WF }(82 \% \text { ext. })+ \\
5 \% \text { DSP }\end{array}$ & $14.20^{\mathrm{bcd}}$ & $6.20^{\mathrm{bc}}$ & $6.80^{\mathrm{abc}}$ & $14.60^{a b c}$ & $6.700^{\mathrm{abc}}$ & $15.30^{b c}$ & $7.30^{\mathrm{ab}}$ & $71.1^{b c}$ \\
\hline No.(7) & $\begin{array}{l}90 \% \text { WF }(82 \% \text { ext. })+ \\
10 \% \text { DSP }\end{array}$ & $13.20^{\mathrm{cd}}$ & $5.80^{\mathrm{bc}}$ & $6.20^{\mathrm{bcd}}$ & $14.00^{\mathrm{bc}}$ & $6.000^{b c}$ & $15.90^{b c}$ & $6.30^{\mathrm{b}}$ & $67.4^{\text {cde }}$ \\
\hline No.(8) & $\begin{array}{l}85 \% \text { WF( }(82 \% \text { ext.) }+ \\
15 \% \text { DSP }\end{array}$ & $0^{\mathrm{de}}$ & $5.20^{\mathrm{bc}}$ & $c^{c d}$ & $b^{b c d}$ & $500^{\mathrm{bc}}$ & $30^{\text {ef }}$ & $5.70^{\mathrm{bc}}$ & $58.4^{\mathrm{e}}$ \\
\hline No.(9) & $\begin{array}{l}80 \% \text { WF( }(82 \% \text { ext. })+ \\
20 \% \text { DSP }\end{array}$ & $8.90^{\mathrm{e}}$ & $4.30^{c}$ & $3.90^{d}$ & $9.80^{d}$ & $4.500^{\circ}$ & $10.80^{\dagger}$ & $4.30^{\circ}$ & $46.5^{\dagger}$ \\
\hline No.(10) & $\begin{array}{l}90 \% \text { WF(82\%ext.) } \\
5 \% \text { FB + 5\% DSP }\end{array}$ & $14.10^{\text {bed }}$ & $6.10^{\mathrm{be}}$ & $6.60^{\mathrm{abc}}$ & $15.10^{a b c}$ & $7.000^{\mathrm{ab}}$ & $14.60^{\mathrm{bcd}}$ & $6.90^{\mathrm{ab}}$ & $70.4^{\mathrm{bcd}}$ \\
\hline No.(11) & $\begin{array}{lll}80 \% & \text { WF( }(82 \% & \text { ext.) } \\
10 \% & \text { FB }+10 \% & \text { DSP }\end{array}$ & $11.40^{\mathrm{de}}$ & $5.50^{\mathrm{be}}$ & $5.40^{\text {cd }}$ & $11.90^{\text {cd }}$ & 6. & $12.60^{\operatorname{def}}$ & $6.20^{b}$ & $59.4^{\mathrm{de}}$ \\
\hline & L.S.D & 0.89 & \begin{tabular}{|l|}
0.68 \\
\end{tabular} & 0.69 & 0.97 & 0.65 & 0.64 & \begin{tabular}{|l|}
0.53 \\
\end{tabular} & 3.24 \\
\hline
\end{tabular}

a-f = Means with the same letter in each column are not significantly different at $\leq 0.05$ WF= wheat flour(82\% ext.). .

$F B=$ fine bran.

$\mathrm{DSP}=$ date seeds powder.

Chemical composition of pan bread samples produced from wheat flour (82\% ext.) containing different levels of fine bran and date seeds powder:

Data presented in Table (5) showed that the chemical composition of pan bread made from wheat flour (82\% ext.) with $5 \%$, $10 \%$ and $15 \%$ fine bran , $5 \%, 10 \%$ date seeds powder and $5 \%$ fine bran $+5 \%$ date seeds powder.

The results indicated that moisture content of pan bread sample No. (3) was the highest $(3.242 \%)$ followed by pan bread sample No.(2) (2.686\%) followed by control sample No. (1) $(2.277 \%)$ and pan bread sample No.(4) (2.092\%). While the lowest moisture content recorded in sample No.(7) $(1.407 \%)$ followed by sample No.(6) (1.253\%) and sample No.(10) (1.133\%). This may be due to the higher fibers content of additives which absorbed more moisture. 
In the same Table, the values of protein in pan bread No.(4) made of $15 \%$ fine bran $G(4)$ was higher than the control sample.

The crude fat content of pan bread samples No.(2), (3), (4), (10), (7) and (6) increased. They recorded $4.177 \%, 4.220 \%, 4.430 \%, 5.030 \%$, $5.107 \%$, and $5.519 \%$ respectively, as compared with the No.(1) control ( $3.952 \%$ ), It could be also noticed from data presented in Table (5) that pan bread sample No.(6) was the highest in fat content recorded (5.519\%).

Ash content of pan bread samples showed that sample No.(10) had the a highest value of ash (3.897\%) compared with other samples No. (6), (7), (4), (3), (2) and (1), they recorded $3.731 \%, 3.414 \%$, $3.338 \%, 3.106 \%, 2.967 \%$ and $2.945 \%$ respectively.

Crude fibers content of pan bread samples No. (2), (3), (4), (6), (7) and (10) were higher than that of control No.(1). This may be due to chemical composition of raw material which showed a high content of crude fibers.

The highest value of carbohydrates in pan bread sample No. (1) $80.228 \%$, as compared with samples No. (2), (3), (4), (7), (6) and (10) which recorded $77.369 \%, 75.936 \%, 74.765 \%, 73.651 \%, 73.670 \%$ and $72.818 \%$, respectively.

From the same Table(5) it could be noticed that the caloric values decreased in all mixtures as compared with the control due to the addition of different additives under study which contained high level of fibers.

The data concluded that the best mixture was that pan bread No.(10) followed by pan bread No.(7) made from $5 \%$ date seeds powder revealed to its lowest calorie value as compared with the other blends.

The low calories diet is beneficial for obesity and diabetes diseases (Jenkins et al., 2002). Also the importance of fibers are increasing due to its beneficial effects of the reduction of cholesterol levels and risk of colon cancer (Anderson, 1991).

Table (5): Chemical composition of pan bread samples produced from wheat flour ( $82 \%$ ext.) containing different levels of fine bran and date seeds powder (on dry weigh basis ):

\begin{tabular}{|c|c|c|c|c|c|c|c|c|}
\hline \multicolumn{2}{|c|}{ Samples } & \multirow{2}{*}{ 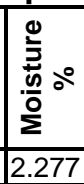 } & \multirow{2}{*}{ 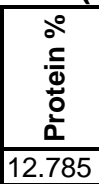 } & \multirow{2}{*}{$\begin{array}{l}\stackrel{\circ}{\circ} \\
\stackrel{\pi}{*} \\
3.952\end{array}$} & \multirow{2}{*}{ 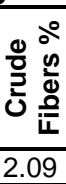 } & \multirow{2}{*}{ 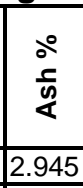 } & \multirow{2}{*}{ 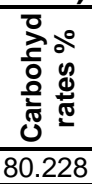 } & \multirow{2}{*}{ 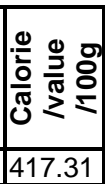 } \\
\hline No.(1) & $100 \%$ WF(82\% ext.) & & & & & & & \\
\hline No.(2) & $95 \% W F(82 \%$ ext.)+5\% FB & 2.686 & 12.787 & 4.177 & 2.70 & 2.967 & 77.369 & 407.65 \\
\hline No.(3) & $90 \%$ WF(82\% ext.) $+10 \% F B$ & 3.242 & 13.478 & 4.220 & 3.26 & 3.106 & 75.936 & 404.99 \\
\hline No.(4) & $85 \%$ WF( $82 \%$ ext. $)+15 \% F B$ & 2.092 & 13.777 & 4.430 & 3.69 & 3.338 & 74.765 & 403.33 \\
\hline No.(6) & $95 \%$ WF(82\% ext.) +5\%DSP & 1.253 & 12.947 & 5.519 & 4.45 & 3.731 & 73.670 & 405.35 \\
\hline No.(7) & $90 \% \mathrm{WF}(82 \%$ ext. $)+10 \%$ DSP & 1.407 & 12.561 & 5.107 & 4.95 & 3.414 & 73.651 & 399.94 \\
\hline No.(10) & $90 \% W F(82 \%$ ext.)+5\%FB+5\%DSP & 1.133 & 12.745 & 5.030 & 5.51 & 3.897 & 72.818 & 396.58 \\
\hline
\end{tabular}


Biological evaluation :.

Effect of supplementing pan bread with fine bran and date seeds powder on serum glucose levels of diabetic rats:-

Table (6) showed that serum glucose of diabetic rats was significantly higher than that of negative control group (1) different periods of investigation.

The same Table(6) showed that the average value of serum glucose and the results observed that serum glucose level was the termined after two weeks of streptozetocin injection and it was found to be raise to an average value ranged from 273.29 to 386.19 $\mathrm{mg} / \mathrm{dl}$ in all groups except negative control group(1) (82.77 $\mathrm{mg} / \mathrm{dl})$.Generally glucose levels were reduced till the end of the experiment.

In case of rats fed on diets containing pan bread made from wheat flour substituted was fine bran and/or date seeds powder, the serum glucose level decreased significantly and ranged from (172.52 to $284.79 \mathrm{mg} / \mathrm{dl}$ ) at the end of the experiment

Table (6): Effect of supplementing pan bread with fine bran and date seeds powder on serum glucose levels of diabetic rats. $(\mathrm{mg} / \mathrm{dl})$ :.

\begin{tabular}{|l|l|c|c|c|}
\hline \multicolumn{2}{|l|}{$\begin{array}{l}\text { variable } \\
\text { Groups }\end{array}$} & \multicolumn{3}{l|}{ Treating time in weeks } \\
\cline { 3 - 5 } G1 & (Negative control) basil diet & $\mathbf{0}$ & $\mathbf{2}$ & $\mathbf{4}$ \\
\hline G2 & (positive control) Diabetic rats fed on basil diet & $154.03^{\mathrm{a}}$ & $386.19^{\mathrm{a}}$ & $297.77^{\mathrm{a}}$ \\
\hline G3 & $100 \%$ wheat flour (82\% ext.) & $141.11^{\mathrm{b}}$ & $368.13^{\mathrm{ab}}$ & $284.79^{\mathrm{a}}$ \\
\hline G4 & $95 \%$ wheat flour(82\% ext.)+fine bran5\% & $128.19^{\mathrm{bcd}}$ & $302.56^{\mathrm{ab}}$ & $240.34^{\mathrm{b}}$ \\
\hline G5 & $90 \%$ wheat flour(82\% ext.)+10\%fine bran & $107.65^{\mathrm{d}}$ & $321.19^{\mathrm{ab}}$ & $214.23^{\mathrm{bc}}$ \\
\hline G6 & $85 \%$ wheat flour(82\% ext.)+15\% fine bran & $112.12^{\mathrm{cd}}$ & $273.29^{\mathrm{b}}$ & $184.05^{\mathrm{cd}}$ \\
\hline G7 & $95 \%$ wheat flour(82\% ext.) +5\%date seed powder & $132.50^{\mathrm{bc}}$ & $297.03^{\mathrm{ab}}$ & $190.35^{\mathrm{cd}}$ \\
\hline G8 & $\begin{array}{l}90 \% \text { wheat flour(82\% ext.) }+10 \% \text { date seed } \\
\text { powder }\end{array}$ & $129.03^{\mathrm{bcd}}$ & $287.63^{\mathrm{ab}}$ & $172.52^{\mathrm{d}}$ \\
\hline G9 & $\begin{array}{l}90 \% \text { wheat flour (82\% ext.)+5\%fine bran } \\
+5 \% \text { date seed powder }\end{array}$ & $119.35^{\mathrm{bcd}}$ & $300.56^{\mathrm{ab}}$ & $177.30^{\mathrm{cd}}$ \\
\hline & L.S.D & 22.817 & 102.72 & 36.97 \\
\hline
\end{tabular}

a-e = Means with the same letter in each column are not significantly different at $\leq 0.05 *$ Significant at $p \leq 0.05$.

Generally, the reduction in serum glucose level may be due to different factors such as high level of fibers. This data is confirmed by the observation of Olagunju et al., (1999), They explained that reduction in serum glucose level may be due to diets high in fibers content tent to have a higher chromium content. Chromium is 
essential for synthesis of glucose tolerance factor, which facilitates these peripheral action of insulin, improved glucose tolerance.

The data concluded that rats fed on pan bread made from different additives to wheat flour ( $82 \%$ ext.) significantly lowered their serum glucose levels as compared with that of the G2(positive control) Diabetic rats.

Effect of supplementing pan bread with fine bran and date seeds powder on cholesterol profile and triglyceride level of diabetic rats at the end of experimental (4 weeks):-

Data in Table (7) revealed that the highest value of total cholesterol is $186.90 \mathrm{mg} / \mathrm{dl}$ (group 2), followed by group (3), (175.63 $\mathrm{mg} / \mathrm{dl}$ ) and group (4), (171.33 $\mathrm{mg} / \mathrm{dl})$, there were significant differences within the other groups. While the lowest value of total cholesterol was $135.00 \mathrm{mg} / \mathrm{dl}$ for group (1) (-ve control) rats fed on basil diet.

These results are in consistence with the observation of ELAdawi, (1997), that the cholesterol has lowering effect attributed the consumption of fibers.

Values serum total cholesterol in groups (3), (4), (5), (6), (7),(8) and (9). were slight less than the positive control $G(2)$. The obtained data agree with Iman, (1998) that date seeds decreased the total cholesterol level by $33 \%$. The reduction in the levels of total cholesterol may be due to the inhibitory effect of the studied dietary fibers on the pancreatic enzymes (Mahfouz, 1992).

From the same table, it could be seen that highest value of triglycerides is $110.23 \mathrm{mg} / \mathrm{dl}$ for group (3) followed by group (4) and group (5) (108.87 mg/dl and $99.80 \mathrm{mg} / \mathrm{dl}$, respectively). The lowest value of triglycerides is $90.83 \mathrm{mg} / \mathrm{dl}$ for group (8). These results are in agreement results obtained by EL Adawi, (1997), who reported that the crude fibers of dried fine bran and date seeds powder deceased the serum triglycerides as compared to the negative control and positive control.

The results listed in Table (7) showed that group (1) (negative control) had the highest $\mathrm{HDL}-\mathrm{c}$ value $(35.50 \mathrm{mg} / \mathrm{dl})$ compared with group (2) (positive control) (26.70 $\mathrm{mg} / \mathrm{dl}$ ).

Also, groups (9), (7) and (8) showed higher HDL-c values which recorded $33.64,33.60$ and $33.27 \mathrm{mg} / \mathrm{dl}$ respectively, as compared with the group (2) (positive control) Diabetes rats (27.07 $\mathrm{mg} / \mathrm{dl})$. These finding is in agreement with results obtained by Ibrahim, (1998), that the hypocholesterolemic effects of fibers occured by the increase of HDL-c level which led to increase in the follow of cholesterol to liver converted to other compounds. The values of LDL-C levels of the negative control $G(1)$ and experimental groups are present in the same Table (7). The data revealed that the highest value of LDL-C is (141.10 $\mathrm{mg} / \mathrm{dl}$ ) for group (2) (positive control) Diabetes rats followed by group (3) $(126.89 \mathrm{mg} / \mathrm{dl})$ and group (4) $(122.39 \mathrm{mg} / \mathrm{dl})$ while, the 
other groups with additives showed that the lower values of LDL-C as compared with the positive control (G2).

The data also showed that group (3) recorded the highest value ofvLDL-c (22.04 mg/dl) and followed by group (4) $(21.77 \mathrm{mg} / \mathrm{dl})$. The lowest value of $v L D L-c$ is $(18.16 \mathrm{mg} / \mathrm{dl})$ for group (8) .

It can be concluded that the best groups were group (6) followed by group (7) followed by group (8) and group (9), which showed a decrease in LDL-c, vLDL-c values and an increase HDL-C values as compared with group (2) (positive control). This may be due to their higher crude fibers content of fine bran or / and date seeds powder.

Table (7): Effect of supplementing pan bread with fine bran and date seeds powder on cholesterol profile and triglyceride level of diabetic rats at the end of experimental (4 weeks):

\begin{tabular}{|c|c|c|c|c|c|}
\hline Groups & $\begin{array}{c}\text { TC } \\
(\mathrm{mg} / \mathrm{dl})\end{array}$ & $\begin{array}{c}\text { TG } \\
(\mathrm{mg} / \mathrm{dl})\end{array}$ & $\begin{array}{l}{ }^{\circ} \mathrm{HDL}-\mathrm{c} \\
\text { (mg/dl) }\end{array}$ & $\begin{array}{l}{ }^{{ }^{\circ} \mathrm{LDL}-\mathrm{C}} \\
\text { (mg/dl) }\end{array}$ & $\begin{array}{c}{ }^{000} \mathrm{vLDL}-\mathrm{c} \\
\text { (mg/dl) }\end{array}$ \\
\hline$G(1)$ & $135.00^{g}$ & $91.00^{\mathrm{e}}$ & $35.50^{a}$ & $81.30^{9}$ & $18.20^{\mathrm{e}}$ \\
\hline$G(2)$ & $186.90^{\mathrm{a}}$ & $95.26^{\mathrm{dc}}$ & $26.70^{\mathrm{e}}$ & $141.15^{\mathrm{a}}$ & $19.05^{\text {cd }}$ \\
\hline $\mathrm{G}(3)$ & $175.63^{b}$ & $110.23^{a}$ & $27.07^{\mathrm{de}}$ & $126.52^{\mathrm{b}}$ & $22.04^{\mathrm{a}}$ \\
\hline$G(4)$ & $171.33^{\mathrm{C}}$ & $108.87^{\mathrm{a}}$ & $27.17^{\text {de }}$ & $122.39^{C}$ & $21.77^{\mathrm{a}}$ \\
\hline$G(5)$ & $147.67^{\mathrm{d}}$ & $99.80^{6}$ & $29.73^{\mathrm{dc}}$ & $97.98^{\mathrm{d}}$ & $19.96^{b}$ \\
\hline $\mathrm{G}(6)$ & $142.03^{\mathrm{e}}$ & $95.24^{\mathrm{dc}}$ & $31.47^{\mathrm{DC}}$ & $91.52^{\mathrm{e}}$ & $19.04^{\text {cd }}$ \\
\hline $\mathrm{G}(7)$ & $141.67^{\text {te }}$ & $96.33^{\mathrm{C}}$ & $33.60^{\mathrm{ab}}$ & $88.81^{1 \mathrm{e}}$ & $19.26^{\mathrm{C}}$ \\
\hline $\mathrm{G}(8)$ & $138.37^{g \dagger}$ & $90.83^{\mathrm{e}}$ & $33.27^{\mathrm{ab}}$ & $86.94^{\dagger}$ & $18.16^{\mathrm{e}}$ \\
\hline $\mathrm{G}(9)$ & $139.52^{\text {fe }}$ & $93.20^{\mathrm{de}}$ & $33.64^{\mathrm{ab}}$ & $87.23^{\dagger}$ & $18.64^{\mathrm{de}}$ \\
\hline L.S.D. & 3.4509 & 2.9744 & 2.7871 & 4.2137 & 0.5938 \\
\hline
\end{tabular}

a-g = Means with the same letter in each column are not significantly different at $\leq 0.05$ *Significant at $\mathrm{p} \leq 0.05$

TC = Total Cholesterol.

LDL= low density lipoprotein.

HDL= high density lipoprotein.

$\mathrm{TG}=$ Triglyceride.

$v L D L=$ very low density lipoprotein.

\section{REFERENCES}

A.A.C.C., (2000). American Association of Cereal Chemists. Cereal laboratory method, American Association of cereal chemists, INC. St. paul. Minnesota. U.S.A.; 15:562-4.

Abd El-Monem, A. M. (1994). Studies on some low calorie foods. M.Sc. Thesis, Food Indust. Dept. Faculty of Agric., EL-Mansoura Univ., Egypt.

A.D.A; (2001). American Diabetes Association. Fiber facts. University of Pittsburgh Medical Center website. http://patiente ducation. Upmc.com /pdf/Fiber Facts. Bdf.

Allain, C.C., Richmond, N . and Rosechloy, P. (1974). Cholesterol enzymat colorimetric test. Clim. Chem., clin, 19, 20, 1350- 470. 
Al-Farsi, M.; Alasalvar, C.; Al-Abid, M., Al-Shoaily,K.; Al-Amry, M. and AlRawahy, F. (2007). Compositional and functional characteristics of dates, syrups, and their by-products. Food Chemistry 104:943-947.

Ammar, A.S. and Habiba, R.A. (2010). Phenolic content and antioxidant activity of date seeds.J.Agric.Veterinary Sciences, Qassim University, $3(1): 3-10$.

Anderson, J. W.; Zeigler, J. A. Deakins, D. A. Floore, T. L. Dillon, D. W. Wood, C. L. Oeltgen P. R. and Whilley, R. J. (1991). Metabolic effects of high carbohydrates, high fiber diet for IDDM in dividuals.Am. J.Clin. Nutr.,54:936-943.

A.O.A.C. (2005). Official Methods of Analysis. Association of Official Analytical Chemists Washington DC, USA.

A.O.A.C. (2007). Official Methods of Analysis. (16 ${ }^{\text {th }}$ End) Association of Official Analytical Chemists Washington DC, USA.

Desai, A.C.: and Bhide, M. B. (1985). Hypoglycaemic activity of haniltonia suaveolens. Indian. J. Med. Res. 81, 86-91. Diabetes. Lancet.360, 783-789.

EL-Adawi, A.S. (1997). Effect of Fiber on Level of Blood Glucose. Home Economics. PhD. Thesis Department of Nutrition and food sciences Faculty of Home Economics. M enoufia University.

EL-Hadidy, G. S. (2009). Chemical and Biological Studies on Some Hypoglycemic Foods. M sc. Thesis, Fac. Agric. Food Technology Dep., Kafrelshiekh Univ.

F.D.A. (2001). Claims that can be made for conventional foods and dietary supplements. Center for Food safety and Applied nutrition. Official of nutritional products. Labeling and Dietary supplements. CFR101.180 Appendix C.Gpo: Wasington, Dc.

Fossati, P. and Principe, L. (1982). Serum triglycerides determined colorimetrically with an enzyme that produces hydrogen peroxide. Clin. Chem.28: 2077-2080.

Friede Wald, W.T.; Levy, R. and Fredrickson, D.S. (1972). High density lipoprotein by selective precipitation. Clin. Chem., 18:499-502.

Hassan., A. A. (2003). The role of high- fiber bread on the reduction of cholesterol triglycerides, liver enzymes and histopathological alteration of experimental hypercholesterolemic rats. Food Sci. Dept. Fac. Agric. Ain Shams Univ., Annals of Agric. Sc., Moshtohor Vol. 41(3) : 1297- 1333.

Hosam . M. Habib; Fatima, .D.; AL Maqbali, N.; Jaber, N. and Wissam, H.I. (2004). Identification of date seeds varieties patterns to optimize nutritional benefits of date seeds. J. Nutr Food Sci. Nutrition and Health Department, College of Food and Agric,United Arab Emirates University, Al Ain, UAE.

Ibrahim.; A.M . R. (1998). Effect of Some Plant Natural Products on Fat Metabolism in Rats PHD. Bio.Dept.Faculty of Agric.,Cairo-Ain Shams University 
Iman. A.I, (1998). Study of the Effect of Some Natural Fibers on Diabetic MSc, Thesis, Home Economics. Department of Nutrition and Food Sciences. Faculty of Home Economics. Helwan Univerisity.

Jenkins, D.J.A; Kendall, C.W.C, and Augustis, L.S.A (2002). Glycemic index: overview of implications in health and disease. Am J Clin Nutr.; 76:266S-73S.

Kumar. P; Yadava, R. K.; Gollen, B.; Kumar, S.; Verma, RK and Yadav, S. (2011). Nutritional contents and medicinal properties of wheat. Life Sciences and Medicine Research, Volume 2011: LSMR-221.

Litwinek,D.; Gambuś,H.; Mickowska,B.; Zięć,G. and Berski,W. (2013). Amino acids composition of proteins in wheat and oat flours used in breads production. $J$. Microbiology, Biotechnology Food Sciences : 2 (Special issue on BQRMF)1725-1733.

Lopez-Virella, M. F.; Stone, P. Ellis, S. and Colwell, J. A. (1977). Cholesterol determination in high density lipoproteins separated by three different methods. Clin Chem,23:882-884.

Mahfouz, M.H. (1992). Effect of Dietary Fiber on Glucose and Lipid Metabolism in Non isulin Dependent Diabetic Patients. M.sc. Thesis Biochemistiry. Faculty of Science. Ain Shams University.

Mohamed .A.A. Soad. (2006). Studies on the production and evalution of some diabetic foods. Msc. Theiss. Department of food Science and Technology. Faculty of Agric. Ain Shams university.

Olagunju J. A.; Jobi, A.A.; Oyedapo, O.O. (1999). An investigation into the biochemical basis of the observed hyperglycaemia in rats treated with ethanol root extract of Plumbago zeylanica. Phytother Res 13: 346-348.

Park, H; Seibe, P.A. and chung, O.K (1997). Fortifying bread with a mixture of wheat fiber and psyllium husk fiber plus three antioxidants. Cereal Chem. 74 (3): 207-211.

Rahman, M. S.; Kasapis, S.; Al-Kharusi, N. S. Z.; Al-Marhubi, I. M. and Khan, A.J.(2007).Composition characterization and thermal transition of date pits powders. journal of Food Engineering 80:1-10.

Soliman, M.A.; Abou-Raya, M.A and Shehata, H. (1993). Improvement of Egyptian balady bread quality produced by using a mixture of wheat and cassava flour. J. Agric. Sci. Mansoura Univ., 18(1): 234-243.

Steel, R.G. and Torrie, J. H. (1980). Principles and Procedures of Statistics Analysis. Mc Grew Hill Book Co. Inc: New York, U. S. A. pp. 663.

Trinder, P. (1969). Determination of plasma and uric acid. Ann. Clin. Bio. Chemistry ; 6:24 
تأثير التغذية بمستويات مختلفة من ردة القمح ومسحوق بذور التمر على

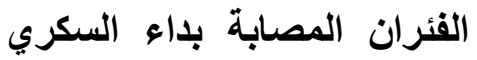

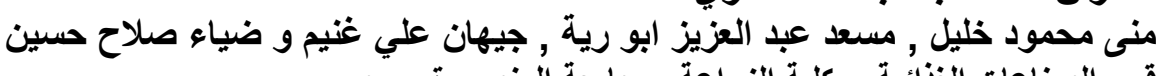

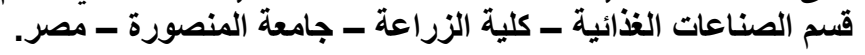

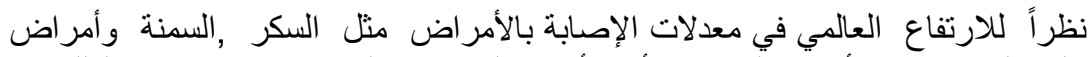

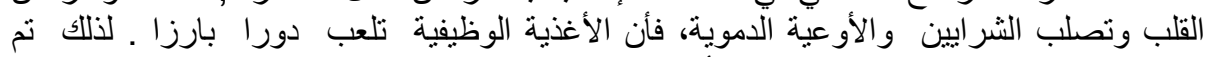

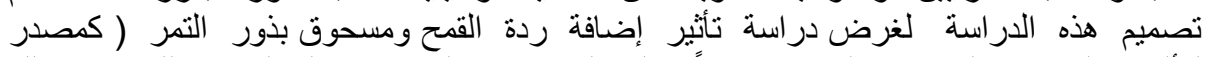

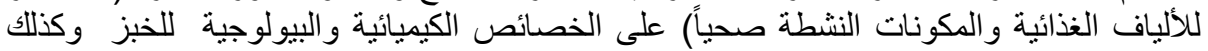

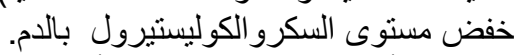

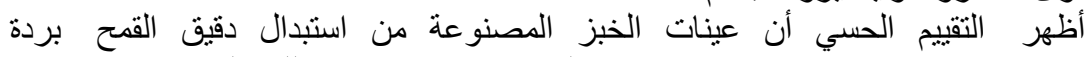

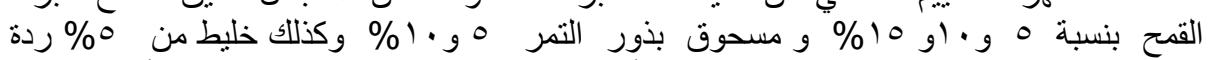

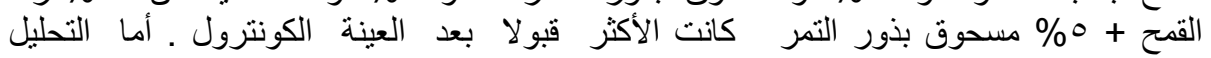

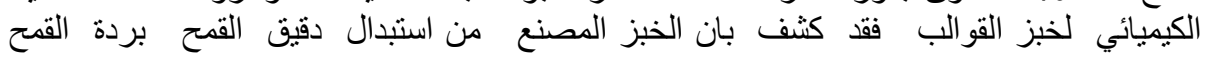

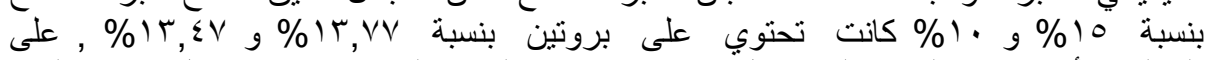

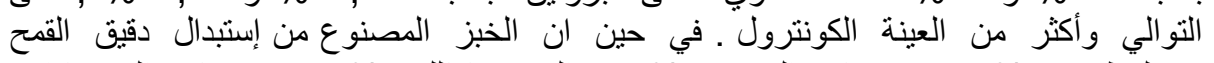

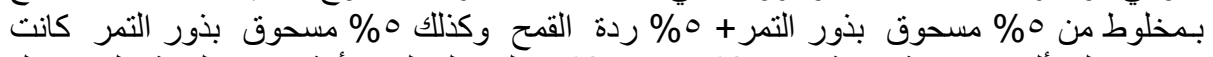

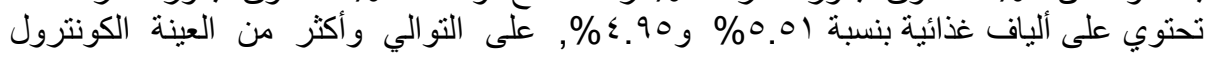

كثف التقييم البيولوجي إن الفئران التي ثم تغذيتها على الخبز المصنع من استبدال

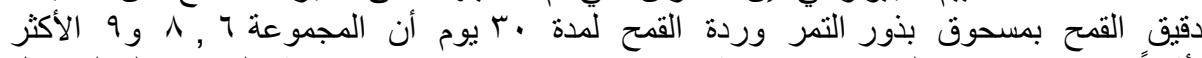

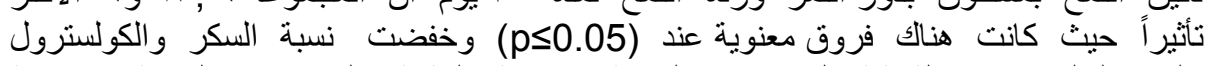

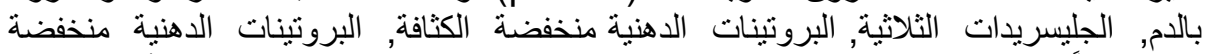

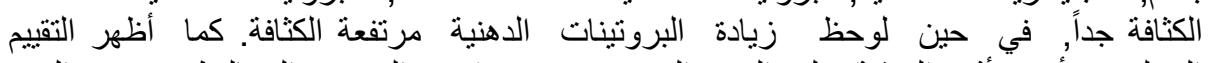

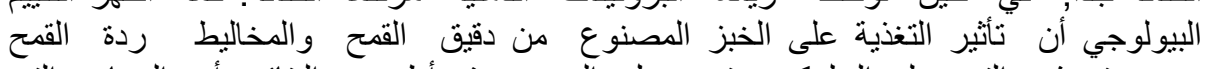

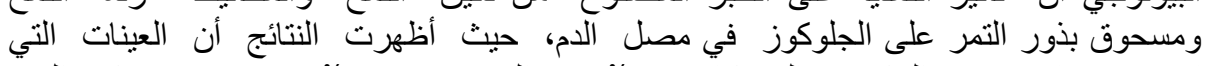

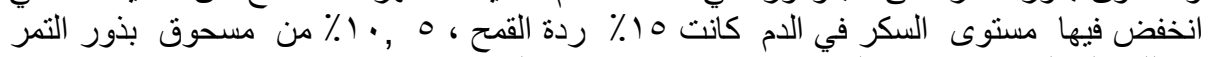

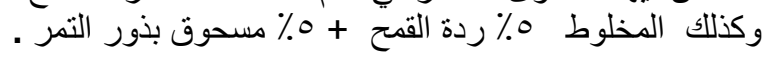

